\title{
PENGARUH MOTIVASI BELAJAR DAN PERSEPSI PESERTA DIDIK ATAS KOMPETENSI PEDAGOGIK GURU TERHADAP PRESTASI BELAJAR SOSIOLOGI
}

\author{
Yunita Endra Megiati \\ Dosen Program Studi Teknik Informatika Universitas Indraprasta PGRI \\ Email : megiati_igem@yahoo.com
}

\begin{abstract}
Abstrak
Tujuan dari penelitian ini adalah untuk mengetahui pengaruh dari motivasi belajar dan persepsi peserta didik atas kompetensi pedagogik guru secara bersama-sama terhadap prestasi belajar Sosiologi. Penelitian Deskriptif ini menggunakan metode penelitian survey dengan sampel berjumlah 57 peserta didik yang dipilih secara acak dari kelas XI SMA Swasta di kecamatan Gunung Putri kebupatian Bogor Jawa Barat Tahun Pelajaran 2012/2013. Data tentang motivasi belajar, persepsi peserta didik atas kompetensi pedagogik guru dan prestasi belajar Sosiologi diperoleh melalui angket yang disusun oleh peneliti. Hasil analisa pengaruh dari motivasi belajar dan persepsi peserta didik atas kompetensi pedagogik guru secara bersama-sama terhadap prestasi belajar Sosiologi diperoleh koefisien korelasi (R) sebesar 0.827 dan koefisien determinasi $\left(\mathrm{R}^{2}\right)$ sebesar 0.684 , serta persamaan garis regresi $\mathrm{Y}=-32.35+0.456 \mathrm{X}_{1}+0.471 \mathrm{X}_{2}$. Hasil pengujian didapatkan bahwa : terdapat pengaruh signifikan motivasi belajar dan persepsi peserta didik atas kompetensi pedagogik guru secara bersama-sama terhadap prestasi belajar Sosiologi.

Kata kunci : motivasi belajar, persepsi peserta didik atas kompetensi pedagogik guru, prestasi belajar
\end{abstract}

\section{PENDAHULUAN}

Pendidikan Nasional yang berdasarkan Pancasila dan Undang-Undang Dasar Negara Republik Indonesia tahun 1945 berfungsi mengembangkan kemampuan dan membentuk watak serta peradaban bangsa yang bermartabat dalam rangka mencerdaskan kehidupan bangsa, bertujuan untuk mengembangkan potensi peserta didik agar menjadi manusia yang beriman dan bertakwa kepada Tuhan yang Maha Esa, berakhlak mulia, sehat, berilmu, cakap, kreatif, mandiri, dan menjadi warga negara yang demokratis serta bertanggungjawab. (UU RI No.20 Tahun 2003 tentang Sisdiknas, Bab II Pasal 2-3)

Kegiatan pembelajaran bertujuan untuk menghasilkan perubahanperubahan yang bersifat positif, sehingga seseorang atau peserta didik dapat menuju kedewasaannya. Perubahan positif yang terjadi menunjukkan adanya hasil dari belajar. Dan prestasi belajar inilah yang sebenarnya menjadi inti dari setiap proses pembelajaran. Dengan kata lain, prestasi belajar merupakan tingkatan hasil belajar yang ditunjukkan seseorang atau peserta didik setelah mendapatkan bimbingan dan latihan oleh guru sebagai fasilitatornya.

Dalam proses belajar, motivasi sangat besar peranannya terhadap prestasi belajar. Dengan adanya motivasi, dapat menumbuhkan minat belajar peserta didik. Bagi peserta didik yang memiliki motivasi yang kuat akan mempunyai keinginan untuk melaksanakan kegiatan belajar. Motivasi yang kuat dari dalam diri peserta didik akan meningkatkan minat, kemauan dan semangat yang tinggi dalam belajar. Motivasi sangat berperan dalam proses belajar, dengan motivasi inilah peserta didik menjadi tekun dalam proses belajar, dan dengan motivasi itu pula kualitas hasil belajardapat diwujudkan dengan baik. Peserta didik yang dalam proses belajar mempunyai motivasi yang kuat dan jelas, akan tekun dan berhasil dalam belajarnya. Dan tingginya motivasi belajar berhubungan dengan tingginya prestasi belajar. 
Adapun guru, merupakan komponen paling menentukan dalam sistem pendidikan secara keseluruhan. Figur guru senantiasa menjadi sorotan jika berkaitan dengan masalah pendidkan, sebab guru selalu terkait dengan komponen manapun dalam sistem pendidikan. Guru memegang peran utama dalam pembangunan pendidikan, khususnya yang diselenggarakan secara formal di sekolah. Guru sangat menentukan keberhasilan peserta didik, terutama dalam kaitannya dengan proses belajar-mengajar. Guru pun merupakan komponen yang paling berpengaruh terhadap terciptanya proses dan hasil pendidikan yang berkualitas. Karenanya kualitas pendidikan berpangkal dari guru dan berujung pada guru pula.

Namun disisi lain ada faktor-faktor yang menyebabkan rendahnya kompetensi guru antara lain disebabkan oleh; (1) masih banyak guru yang tidak menekuni profesinya secara utuh. Hal ini disebabkan oleh sebagian guru yang bekerja diluar jam kerjanya untuk memenuhi kebutuhan hidup sehari-hari sehingga tidak memiliki kesempatan untuk meningkatkan diri, baik membaca, menulis, ataupun membuka internet; (2) belum adanya standar profesional guru sebagaimana tuntutan di negara-negara maju; (3) kemungkinan disebabkan oleh adanya perguruan tinggi swasta yang mencetak guru asal jadi atau setengah jadi tanpa memperhitungkan outputnya kelak di lapangan, sehingga menyebabkan banyaknya guru yang tidak patuh pada etika profesinya; (4) kurangnya motivasi guru dalam meningkatkan kualitas diri karena guru tidak dituntut untuk meneliti sebagaimana diberlakukan pada dosen di perguruan tinggi.(Encon Mulyasa, 2009:10)

Lebih lanjut dikemukakan bahwa berdasarkan kondisi tersebut diatas, sedikitnya terdapat dua kategori kompetensi yang harus dimiliki guru, yakni; (1) kompetensi profesional, yaitu kemahiran merancang, melaksanakan, dan menilai tugas sebagai guru, yang meliputi penguasaan ilmu pengetahuan dan teknologi pendidikan, dan (2) kompetensi personal, yang meliputi etika, moral, pengabdian, kemampuan sosial dan spiritual. Dimana kompetensi pertama dapat ditumbuhkan dan ditingkatkan melalui proses pendidikan akademik dan profesi suatu lembaga pendidikan. Sedangkan kompetensi kedua merupakan kristalisasi pengalaman dan pergaulan seorang guru yang terbentuk dalam lingkungan keluarga, masyarakat dan sekolah tempat melaksanakan tugas.(Encon Mulyasa, 2009:10)

Seorang guru tidak hanya dituntut untuk menguasai bidang ilmu, bahan ajar, metode pembelajaran, memotivasi peserta didik, memiliki keterampilan yang tinggi dan wawasan yang luas terhadap dunia pendidikan, tetapi juga harus memiliki pemahaman yang mendalam tentang hakikat manusia, dan masyarakat. Hakikathakikat ini akan melandasi pola pikir dan budaya kerja guru, serta loyalitasnya terhadap profesi pendidikan. Dalam hal pembelajaran, guru diharapkan mampu mengembangkan budaya dan juga iklim organisasi pembelajaran yang bermakna, kreatif dan dinamis, bergairah, dialogis, sehingga menyenangkan bagi para peserta didik maupun para guru.

Dan guru yang memiliki kompetensi tinggi serta mengaplikasikannya dalam proses belajar mengajar akan memiliki seribu satu keahlian dalam melaksanakan tugas mengajarnya, sehingga dalam memecahkan persoalanpersoalan yang dialaminya dalam proses belajar mengajar dengan mudah didapatkan pemecahannya, dan pada akhirnya berdampak kepada prestasi belajar peserta didik di kelasnya. 


\section{TINJAUAN PUSTAKA}

\section{Teori Prestasi Belajar Sosiologi}

Proses belajar dapat melibatkan aspek kognitif, afektif, dan psikomotorik. Pada belajar kognitif, prosesnya mengakibatkan perubahan dalam aspek kemampuan berpikir (cognitive), pada belajar afektif mengakibatkan perubahan dalam kemampuan merasakan (afective), sedang belajar psikomotorik memberikan hasil belajar berupa keterampilan (psychomotorik).

Pada dasarnya proses belajar itu sendiri merupakan proses yang unik dan kompleks. Keunikan itu disebabkan karena hasil belajar hanya terjadi pada individu yang belajar, tidak pada orang lain, dan setiap individu menampilkan perilaku belajar yang berbeda. Perbedaan penampilan itu disebabkan karena setiap individu mempunyai karakteristik individual yang khas, seperti minat, intelegensi, perhatian, bakat, dan lain sebagainya.

Setiap peserta didik tidak ada yang sama, perbedaan individual yang menyebabkan perbedaan tingkah laku belajar, sehingga menyebabkan perbedaan dalam prestasi belajar. Prestasi belajar merupakan hasil dari suatu proses yang didalamnya terdapat sejumlah faktor yang saling mempengaruhi, sehingga dapat mempengaruhi tinggi rendahnya prestasi peserta didik. Manusia mempunyai cara yang khas untuk mengusahakan proses belajar terjadi dalam dirinya. Individu yang berbeda dalam aspek kognitif, afektif, dan psikomotorik. Begitu pula, individu yang sama mempunyai kemampuan yang berbeda dalam belajar aspek kognitif, afektif, dan psikomotorik.(Purwanto, 2011:23)

Definisi Prestasi adalah hasil yang telah dicapai atau dilakukan dari yang telah dikerjakan atau dilakukan. Dan prestasi belajar adalah penguasaan pengetahuan atau keterampilan yang dikembangkan melalui mata pelajaran, lazimnya ditunjukkan dengan nilai tes atau angka nilai yang diberikan oleh guru. (KBBI, 2005 : 895) Dan prestasi belajar dapat pula diartikan sebagai tingkat keberhasilan dalam mempelajari materi pelajaran disekolah yang dinyatakan dalam bentuk skor yang diperoleh dari hasil tes mengenai sejumlah materi pelajaran tertentu. (Depdikbud, 1990:23)

Secara umum prestasi belajar dipengaruhi oleh beberapa faktor:

1. Faktor internal

Yang termasuk faktor internal adalah :

a. Faktor jasmaniah (fisiologis), misalnya : penglihatan, pendengaran, struktur tubuh dan sebagainya.

b. Faktor Psikologis, terdiri atas:

1) Faktor intelektif yang meliputi faktor potensial yaitu kecerdasan dan bakat dan faktor kecakapan yaitu prestasi yang telah dimiliki.

2) Faktor non-intelektif, yaitu unsur-unsur kepribadian tertentu seperti: sikap, kebiasaan, minat, kebutuhan, motivasi, emosi dan penyesuaian diri.

c. Faktor kematangan fisik dan psikis.

2. Faktor eksternal

Yang meliputi faktor sosial, budaya, lingkungan fisik dan lingkungan

fisik dan lingkungan spiritual atau keagamaan.

Sedangkan keberhasilan dalam proses belajar mengajar dapat dicapai dengan dukungan faktor-faktor berikut: 
1. Tujuan sebagai pedoman dan sasaran yang akan dicapai dalam kegiatan belajar mengajar.

2. Guru adalah tenaga pendidik yang memberikan sejumlah ilmu pengetahuan kepada anak didik di sekolah dan berpengalaman dalam bidang profesinya.

3. Anak didik atau peserta didik (siswa) adalah orang yang dengan sengaja datang ke sekolah untuk menuntut ilmu.

4. Kegiatan pengajaran. Pola umum kegiatan pengajaran adalah terjadinya interaksi antara guru dengan siswa (peserta didik) dan bahan pelajaran sebagai perantaranya.

5. Bahan dan alat tes. Bahan tes adalah suatu bahan yang terdapat di dalam kurikulum yang sudah dipelajari oleh siswa guna kepentingan ulangan.

6. Suasana tes. Pelaksanaan tes biasanya dilaksanakan di dalam kelas dan dijaga oleh satu atau dua orang pengawas, sehingga siswa dapat bekerja sendiri dan bersikap jujur dalam melaksanakan tes. (Syaiful Bahri Djamarah, 2008:121)

Sehingga dapat disimpulkan prestasi belajar adalah hasil yang dicapai peserta didik di sekolah yang ditunjukkan dengan terjadinya perubahan pengetahuan, keterampilan dan sikap sebagai hasil suatu individu itu sendiri dalam berinteraksi dengan lingkungannya.

Mata pelajaran Sosiologi merupakan salah satu mata pelajaran yang diajarkan di sekolah. Pembelajaran Sosiologi dimaksudkan untuk mengembangkan kemampuan pemahaman fenomena kehidupan sehari-hari, materi pelajarannya mencakup konsep-konsep dasar, pendekatan, metode, dan teknik analisis dalam pengkajian berbagai fenomena dan permasalahan yang ditemui dalam kehidupan nyata di masyarakat. Mata pelajaran Sosiologi diberikan pada tingkat pendidikan dasar sebagai bagian integral dari Ilmu Pengetahuan Sosial (IPS), sedangkan pada tingkat pendidikan menengah diberikan sebagai mata pelajaran tersendiri.

Hakekatnya Sosiologi mempelajari perilaku manusia dalam kelompokkelompok. Dimana perhatian utamanya adalah dalam hubungan sosial manusia, perilaku manusia seperti diwujudkan sendiri dalam perkembangan dan fungsi dari kelompok dan intitusi.

Lebih lanjut, Sosiologi adalah istilah yang berasal dari kata Latin 'socius' yang artinya 'teman', dan 'logos' dari kata Yunani yang berarti 'cerita'. Diungkapkan pertama kali dalam buku yang berjudul "Cours De Philosophie Positive" karangan August Comte (1798-1857). Sosiologi muncul sejak ratusan bahkan ribuan tahun lalu. Namun Sosiologi sebagai ilmu yang dipelajari masyarakat, baru lahir kemudian di Eropa. Sejak awal Masehi hingga abad 19, Eropa dapat dikatakan menjadi pusat tumbuhnya peradaban dunia, dimana pada saat itu para ilmuwan mulai menyadari perlunya secara khusus mempelajari kondisi dan perubahan sosial. ( Iif Khoiru Ahmadi dan Sofan Amri, 2011:131)

Sosiologi mempunyai ciri-ciri sebagai berikut :

1. Empiris, adalah ciri utama sosiologi sebagai ilmu. Sebab ia bersumber dan diciptakan dari kenyataan yang terjadi dilapangan.

2. Teoritis, adalah peningkatan fase penciptaan yang tadi menjadi salah satu bentuk budaya yang bisa disimpan dalam waktu lama dan dapat diwariskan kepada generasi muda. 
3. Komulatif, sebagai akibat dari penciptaan terus-menerus sebagai konsekuensi dari terjadinya perubahan di masyarakat, yang membuat teori-teori itu akan berkomulasi mengarah kepada teori yang lebih baik.

4. Non-etis, karena teori itu menceritakan apa adanya tentang masyarakat beserta individu-individu di dalamnya, tidak menilai apakah hal itu baik atau buruk. (Made Pidarta, 2007:151),

Sehingga dapat disimpulkan Sosiologi adalah ilmu yang mempelajari hubungan antara manusia dalam kelompok-kelompok dan struktur sosialnya. Di dalam Sosiologi dipelajari bagaimana manusia itu berhubungan satu dengan yang lain dalam kelompoknya dan bagaimana susunan unit-unit masyarakat atau sosial di suatu wilayah serta kaitannya satu dengan yang lain.

Pelajaran Sosiologi di sekolah diharapkan dapat menjadi wahana bagi peserta didik untuk mempelajari diri sendiri dan hubungan sosial masyarakat sekitarnya, serta prospek pengembangan lebih lanjut dalam menerapkannya dalam kehidupan sehari-hari. Pembelajaran ini menekankan pada pengalaman secara langsung untuk mengembangkan kompetensi peserta didik dapat memahami perilaku individu dan berhubungan dengan masyarakat sekitarnya sehingga membantu untuk memperoleh pemahaman yang lebih mendalam.

\section{Teori Motivasi Belajar}

Motivasi berasal dari kata Latin Movere yang berarti dorongan atau menggerakkan. Kata motivasi sering diartikan dalam bentuk kata kerja menjadi rangsangan, dorongan yang menyebabkan sesuatu terjadi, baik yang berasal dari dalam maupun yang berasal dari luar diri seseorang atau lingkungannya. Lebih lanjut, motivasi adalah proses yang memberi semangat, arah, dan kegigihan perilaku. Artinya, perilaku yang termotivasi adalah perilaku yang penuh energi, terarah dan bertahan lama.(Sudarwan Danim, 2009 : 30)

Adapun hakikat motivasi belajar adalah "dorongan internal dan eksternal pada siswa-siswa atau peserta didik yang sedang belajar untuk mengadakan perubahan tingkah laku, pada umumnya dengan beberapa indikator atau unsur yang mendukung. Hal itu mempunyai peranan besar dalam keberhasilan seseorang dalam belajar. Indikator motivasi belajar dapat diklasifikasikan sebagai berikut : (1) adanya hasrat dan keinginan berhasil; (2) adanya dorongan dan kebutuhan dalam belajar; (3) adanya harapan dan cita-cita masa depan; (4) adanya penghargaan dalam belajar; (5) adanya kegiatan yang menarik dalam belajar; (6) adanya lingkungan belajar yang kondusif sehingga memungkinkan seorang siswa atau peserta didik dapat belajar dengan baik".(Hamzah B. Uno, 2008 : 23)

Dalam kegiatan belajar, motivasi dapat dikatakan sebagai keseluruhan daya penggerak di dalam diri siswa (peserta didik) yang menimbulkan, menjamin kelangsungan dan memberikan arah kegiatan belajar sehingga diharapkan tujuan yang ada dapat tercapai.(Pupuh Fathurrohman dan M. Sobry Sutikno, 2009:19)

Sehingga jelas bahwa dalam setiap kegiatan belajar motivasi tentu sangat diperlukan, sebab seseorang atau peserta didik yang tidak mempunyai motivasi dalam belajar tidak akan mungkin melakukan aktivitas belajar. Sebagaimana yang telah dijelaskan di atas bahwa motivasi merupakan faktor yang mempunyai arti penting bagi peserta didik. Apalah artinya bagi seorang anak pergi ke sekolah tanpa mempunyai motivasi belajar. Bahwa diantara sebagian peserta didik ada yang 
mempunyai motivasi untuk belajar dan sebagian lain belum termotivasi untuk belajar. Seorang guru melihat perilaku seperti itu, maka perlu diambil langkahlangkah untuk membangkitkan motivasi belajarnya.

Membangkitkan motivasi belajar tidaklah mudah, guru harus dapat menggunakan berbagai macam cara untuk memotivasi belajar. Cara membangkitkan motivasi belajar diantaranya adalah :

1. Menjelaskan kepada peserta didik, alasan suatu bidang studi dimasukkan dalam kurikulum dan kegunaannya untuk kehidupan.

2. Mengkaitkan materi pelajaran dengan pengalaman peserta didik di luar lingkungan sekolah.

3. Menunjukkan antusias dalam mengajar bidang studi yang dipegang.

4. Mendorong peserta didik untuk memandang belajar di sekolah sebagai suatu tugas yang tidak harus serba menekan, sehingga peserta didik mempunyai intensitas untuk belajar dan menjelaskan tugas dengan sebaik mungkin.

5. Menciptakan iklim dan suasana dalam kelas yang sesuai dengan kebutuhan peserta didik.

6. Memberikan hasil ulangan dalam waktu sesingkat mungkin.

7. Menggunakan bentuk -bentuk kompetisi (persaingan) antar peserta didik.

8. Menggunakan intensif seperti pujian, hadiah secara wajar. (Pupuh Faturrohman dan M. Sobry Sutikno, 2009:20)

Di dalam kegiatan belajar mengajar peranan motivasi baik instrinsik maupun ekstrinsik sangat diperlukan. Dengan motivasi, peserta didik dapat mengembangkan aktivitas dan inisiatif, dapat mengarahkan dan memelihara ketekunan dalam melakukan kegiatan belajar.

Namun dalam kaitan itu, perlu diketahui bahwa cara dan jenis untuk menumbuhkan motivasi seseorang adalah bermacam-macam. Dalam hal ini guru harus berhati-hati dalam menumbuhkan dan memberi motivasi bagi kegiatan belajar peserta didik. Sebab mungkin maksudnya memberikan motivasi tetapi justru tidak menguntungkan bagi perkembangan anak itu sendiri.

Ada beberapa bentuk dan cara untuk menumbuhkan motivasi dalam kegiatan belajar di sekolah, diantaranya :

1. Memberi angka

Angka dalam hal ini sebagai simbol dari nilai kegiatan belajarnya. Angkaangka yang baik itu bagi peserta didik merupakan motivasi yang sangat kuat. Namun bagi para guru perlu diingat bahwa hasil belajar yang bermakna diperlukan values yang terkandung di dalam setiap pengetahuan yang diajarkan tidak hanya sekedar kognitifnya saja, namun juga keterampilan dan afeksinya.

2. Hadiah

Hadiah dapat juga dikatakan sebagai motivasi, tetapi tidak selalu demikian. Pada peserta didik yang berprestasi hal ini akan memacu semangat mereka untuk bisa belajar lebih giat lagi, dan bagi peserta didik yang belum berprestasi akan termotivasi untuk bisa mengejar peserta didik yang berprestasi.

3. Ego-involment

Menumbuhkan kesadaran kepada peserta didik agar merasakan pentingnya tugas dan menerimanya sebagai tantangan sehingga bekerja keras dengan mempertaruhkan harga diri, adalah sebagai salah satu bentuk motivasi yang cukup penting. 
4. Saingan atau kompetisi

Saingan atau kompetensi dapat digunakan sebagai alat motivasi untuk mendorong belajar peserta didik.

5. Memberi ulangan

Peserta didik akan menjadi giat belajar kalau mengetahui akan ada ulangan. Oleh karena itu, memberi ulangan ini juga merupakan sarana motivasi. Namun dalam hal ini guru juga harus terbuka, maksudnya kalau akan ulangan harus diberitahukan kepada peserta didiknya

6. Mengetahui hasil

Dengan mengetahui hasil pekerjaan, apalagi jika terjadi kemajuan akan mendorong peserta didik untuk lebih giat belajar.

7. Pujian

Pujian adalah bentuk reinforcement yang positif dan sekaligus merupakan motivasi yang baik.

8. Hukuman

Hukuman sebagai reinforcement yang negatif, tetapi jika diberikan secara bijak dan tepat dapat menjadi alat motivasi. Oleh karenanya guru harus memahami prinsip-prinsip pemberian hukuman.

9. Hasrat untuk Belajar

Hasrat untuk belajar, berarti adanya unsur kesengajaan, ada maksud untuk belajar. Hasrat untuk belajar berarti pada diri peserta didik memang ada motivasi untuk belajar, sehingga sudah tentu hasilnya akan lebih baik.

10. Minat

Motivasi muncul karena adanya kebutuhan, begitu pula minat. Sehingga tepat kalau minat merupakan alat motivasi yang pokok. Proses belajar akan berjalan lancar jika disertai dengan minat.

11. Tujuan yang diakui

Rumusan tujuan yang diakui dan diterima baik oleh peserta didik merupakan alat motivasi yang sangat penting. Sebab dengan memahami tujuan yang harus dicapai akan dirasa sangat berguna dan menguntungkan, maka akan timbul gairah untuk terus belajar.(Sardiman AM.,2010:92-95)

Dari beberapa uraian diatas, dapat disimpulkan bahwa motivasi dapat dikatakan sebagai keseluruhan daya penggerak di dalam diri peserta didik yang menimbulkan, menjamin kelangsungan dan memberikan arah kegiatan belajar sehingga diharapkan tujuan yang ada dapat tercapai. Nampak jelas bahwa motivasi berfungsi sebagai pendorong, pengarah, dan sekaligus sebagai penggerak perilaku seseorang atau peserta didik untuk mencapai suatu tujuan. Dan guru merupakan faktor yang penting di dalam usaha melaksanakan fungsi-fungsi tersebut dengan berbagai cara dan terutama ditujukan untuk memenuhi kebutuhan peserta didiknya.

\section{Teori Persepsi Peserta Didik Atas Kompetensi Pedagogik Guru}

Persepsi dapat diartikan sebagai tanggapan atau penerimaan langsung dari sesuatu; serapan atau proses seseorang mengetahui beberapa hal melalui panca inderanya. (Kamus Besar Bahasa Indonesia, 2005:863)

Lebih lanjut dijelaskan persepsi adalah proses yang menyangkut masuknya pesan atau informasi kedalam otak manusia. Melalui persepsi, manusia terus menerus mengadakan hubungan dengan lingkungannya. Hubungan ini dilakukan 
lewat inderanya, yaitu indera penglihat, pendengar, peraba, perasa, dan pencium. (Slameto, 2010:102)

Sebelum terjadi persepsi pada manusia, diperlukan sebuah stimuli yang harus ditangkap melalui organ tubuh yang bisa digunakan sebagai alat bantunya untuk memahami lingkungannya. Alat bantu itu itu dinamakan alat indera. Alat indera yang saat ini secara universal diketahui adalah hidung, mata, telinga, lidah dan kulit dan kelima indera tersebut memiliki fungsi-fungsi tersendiri. Persepsi berlangsung saat seseorang menerima stimulus dari dunia luar yang ditangkap oleh organ-organ bantunya yang kemudian masuk ke dalam otak. Di dalamnya terjadi proses berpikir yang pada akhirnya terwujud dalam sebuah pemahaman. Pemahaman ini yang kurang lebih disebut persepsi. (Sarlito W. Sarwono,2010:85)

Dari beberapa uraian diatas dapat diketahui bahwa stimulus atau rangsangan yang baik dari seorang guru dalam proses belajar mengajar, akan menghasilkan persepsi yang baik pada hasil belajar peserta didik. Keberhasilan dalam belajar dapat dicapai apabila transformasi ilmu dari guru dapat diserap dengan baik oleh peserta didik. Meskipun tidak semua peserta didik dapat mengejar nilai baik, tetapi dapat memahami dan mengaplikasikannya dalam kehidupan sehari-harinya. Sehingga tidak hanya sisi kognitif peserta didik yang dipenuhi, namun sisi afektif dan psikomotoriknya juga harus diperhatikan.

Dengan demikian dapat diketahui bahwa apabila seorang guru benar-benar memiliki kompetensi pedagogik dalam hal belajar mengajaryang baik, diharapkan peserta didik akan berhasil dalam menempuh pembelajarannya dengan baik pula.

Guru dalam mengajar pada dasarnya merupakan suatu usaha untuk menciptakan kondisi yang mendukung dan memungkinkan untuk berlangsungnya proses belajar. Untuk mendapatkan hasil belajar yang optimal banyak dipengaruhi oleh komponen belajar mengajar. Guru sebagai salah satu sumber belajar hendaknya mampu menyediakan kondisi kelas yang kondusif dalam kegiatan belajar di kelas.

Dalam UU Nomor 14 tahun 2005 tentang Guru dan Dosen pada Bab 1 Pasal 1 ayat 1; Guru adalah pendidik profesional dengan tugas utama mendidik, mengajar, membimbing, mengarahkan, melatih, menilai, dan mengevaluasi peserta didik pada pendidikan usia dini, jalur pendidikan formal, pendidikan dasar dan pendidikan menengah. Selain memberikan sejumlah ilmu pengetahuan, guru juga bertugas menanamkan nilai-nilai dan sikap kepada peserta didik agar peserta didik memiliki kepribadian yang paripurna. Dengan keilmuan yang dimilikinya, guru membimbing peserta didik dalam mengembangkan potensinya.

Lebih lanjut dikemukakan, guru adalah tenaga pendidik yang tugas utamanya mengajar, dalam arti mengembangkan ranah cipta, rasa, dan karsa siswa sebagai implementasi konsep ideal mendidik. Sedangkan karakteristik kepribadian guru meliputi fleksibilitas kognitif, dan keterbukaan psikologis. (Muhibbin Syah, 2001:256),

Karenanya seorang guru juga dituntut untuk menguasai berbagai kompetensi atau kecakapan dalam melaksanakan profesi keguruannya agar dapat menciptakan lingkungan belajar yang baik bagi peserta didik, sehingga tujuan pengajaran dapat tercapai dengan optimal. Hal ini menunjukkan betapa pentingnya peran seorang guru dalam menentukan keberhasilan proses belajar mengajar. Sebagai perwujudannya, salah satu kegiatan yang harus dilakukan oleh guru adalah melakukan pemilihan dan penentuan sarana pembelajaran yang tepat. Dan setiap 
kompetensi mempunyai karakteristik yang berbeda sehingga pemilihan media belajar dalam mengajar pun harus disesuaikan agar peserta didik tidak mendapatkan kesulitan dalam mempelajarinya. Kemampuan atau kompetensi merupakan perilaku yang rasional untuk mencapai tujuan yang dipersyaratkan sesuai kondisi yang diharapkan. Perilaku yang rasional merupakan wujud dari kemampuan seseorang. Yang dapat diartikan bahwa orang yang memiliki suatu kemampuan adalah benar-benar orang yang mempunyai keahlian dibidangnya.

Kompetensi merupakan komponen utama dari standar profesi di samping kode etik sebagai regulasi perilaku profesi yang ditetapkan dalam prosedur dan sistem pengawasan tertentu. Kompetensi diartikan dan dimaknai sebagai perangkat perilaku efektif yang terkait dengan eksplorasi dan investigasi, menganalisis dan memikirkan, serta memberikan perhatian, dan mempersepsi yang mengarahkan seseorang menemukan cara-cara untuk mencapai tujuan tertentu secara efektif dan efisien. Kompetensi bukanlah suatu titik akhir dari suatu upaya, melainkan suatu proses yang berkembang dan untuk belajar sepanjang hayat (lifelong learning process).

Dalam UU Nomor 14 tahun 2005 Bab 1 pasal 1 ayat 10; Kompetensi adalah seperangkat pengetahuan, keterampilan, dan perilaku yang harus dimiliki, dihayati, dan dikuasai oleh guru atau dosen dalam melaksanakan tugas keprofesionalan. Lebih lanjut dalam bab $1 \mathrm{~V}$ pasal 10 ayat 1 dijabarkan bahwa kompetensi guru sebagaimana dimaksud dalam pasal 8 meliputi kompetensi kepribadian, kompetensi sosial, dan kompetensi profesional yang diperoleh melalui pendidikan profesi.

Kompetensi guru merupakan perpaduan antara kemampuan personal, keilmuan, teknologi, sosial, dan spiritual yang secara kaffah membentuk kompetensi standar profesi guru, yang mencakup penguasaan materi, pemahaman terhadap peserta didik, pembelajaran yang mendidik, pengembangan pribadi dan profesionalisme.Penguasaan materi meliputi ; pemahaman karakteristik dan substansi ilmu sumber bahan pembelajaran, pemahaman disiplin ilmu yang bersangkutan dalam konteks yang lebih luas, penggunaan metodologi ilmu yang bersangkutan untuk memverifikasi dan memantapkan pemahaman konsep yang dipelajari, penyesuaian substansi dengan tuntutan dan ruang gerak kurikuler, serta pemahaman manajemen pembelajaran. (Encon Mulyasa, 2009:26)

Sedangkan dalam Undang-Undang Republik Indonesia Nomor 14 Tahun 2005 tentang Guru dan Dosen Bab III pasal 7, dikemukakan bahwa profesi guru merupakan bidang pekerjaan khusus yang dilaksanakan berdasarkan prinsip-prinsip sebagai berikut :

1. Memiliki bakat, minat, panggilan jiwa, dan idealisme;

2. Memiliki komitmen untuk meningkatkan mutu pendidikan, keimanan, ketakwaan, dan ahlak mulia;

3. Memiliki kualifikasi akademik dan latar belakang pendidikan sesuai dengan bidang tugas;

4. Memiliki kompetensi yang diperlukan sesuai dengan bidang tugas;

5. Memiliki tanggungjawab atas pelaksanaan tugas keprofesionalan;

6. Memperoleh penghasilan yang ditentukan sesuai dengan prestasi kerja;

7. Memiliki kesempatan untuk mengembangkan keprofesionalan secara berkelanjutan dengan belajar sepanjang hayat; 
8. Memiliki jaminan perlindungan hukum dalam melaksanakan tugas keprofesionalan; dan

9. Memiliki organisasi profesi yang mempunyai kewenangan mengatur hal-hal yang berkaitan dengan tugas keprofesionalan guru.

Adapun dalam Peraturan Pemerintah Republik Indonesia Nomor 19 tahun 2005 tentang Standar Nasional Pendidikan, Bab VI penjelasan pasal 28 ayat (3) dikemukakan bahwa (a) Kompetensi Pedagogik adalah kemampuan mengelola pembelajaran peserta didik yang meliputi pemahaman terhadap peserta didik, perancangan dan pelaksanaan pembelajaran, evaluasi hasil belajar, dan pengembangan peserta didik untuk mengaktualisasikan berbagai potensi yang dimilikinya. (b) Kompetensi Kepribadian adalah kemampuan kepribadian yang mantap, stabil, dewasa, arif, dan berwibawa, menjadi teladan bagi peserta didik, dan berakhlak mulia. (c) Kompetensi Profesional adalah kemampuan penguasaan materi pembelajaran secara luas dan mendalam yang memungkinkan membimbing peserta didik memenuhi standar kompetensi yang ditetapkan dalam Standar Nasional Pendidikan. (d) Kompetensi Sosial adalah kemampuan guru sebagai bagian dari masyarakat untuk berkomunikasi dan bergaul secara efektif dengan peserta didik, sesama pendidik, tenaga kependidikan, orang tua/wali peserta didik, dan masyarakat sekitar.

Indikator kompetensi pedagogik guru meliputi; (1) pemahaman terhadap peserta didik, (2) perancangan dan pelaksanaan pembelajaran, (3) evaluasi hasil belajar, dan (4) pengembangan peserta didik untuk mengaktualisasikan berbagai potensi yang dimilikinya.

Adapun persepsi peserta didik mengenai kompetensi pedagogik guru diartikan sebagai tanggapan dari diri peserta didik yang diperoleh melalui proses dengan bantuan inderanya untuk mengetahui atau mengenali seperangkat kemampuan dan kewenangan guru dalam melaksanakan kewajiban-kewajibannya secara bertanggungjawab dan layak dalam mengelola pembelajaran peserta didik.

\section{Pengaruh Motivasi Belajar dan Persepsi Peserta Didik atas Kompetensi Pedagogik Guru secara bersama-sama terhadap Prestasi Belajar Sosiologi}

Prestasi belajar Sosiologi adalah indikator proses belajar mengajar Ilmu Sosiologi yang dipengaruhi oleh beberapa faktor salah satunya adalah metode pembelajaran. Keterampilan mengadakan variasi dalam proses belajar mengajar meliputi tiga aspek yaitu variasi dalam gaya mengajar, variasi dalam menggunakan media dan bahan pelajaran dan variasi dalam interaksi antara guru dan peserta didik. (Syaiful Bahri Djamarah, 2008:180). Penggunaan metode belajar yang bervariasi akan mendorong peserta didik berfikir kreatif dan kritis sehingga tidak akan membuat bosan dalam belajar Sosiologi. Hal tersebut didukung oleh tingkat kompetensi pedagogik guru dan komitmen yang tinggi, secara otomatis motivasi peserta didik untuk belajar Sosiologi akan lebih tinggi. Sehingga pada akhirnya hasil belajarnya akan baik, yang berakibat prestasi belajar juga akan baik. Sebaliknya jika kompetensi pedagogik guru rendah dapat berpengaruh tidak baik terhadap hasil belajarnya, dan otomatis akan membuat motivasi belajar peserta didik untuk belajar Sosiologi akan rendah pula.

Prestasi peserta didik dalam pencapaian tujuan pembelajaran mata pelajaran Sosiologi adalah merupakan hasil belajar Sosiologi mengenai pengetahuan, pemahaman, keterampilan dan nilai sikap terhadap mata pelajaran Sosiologi 
peserta didik yang dapat dicapai apabila ada: (1) Motivasi belajar Sosiologi yang merupakan keseluruhan daya penggerak atau dorongan didalam diri peserta didik yang menimbulkan kegiatan belajar untuk memperoleh pengetahuan, pemahaman, keterampilan, dan nilai sikap terhadap mata pelajaran Sosiologi. Dimana peserta didik yang mempunyai motivasi belajar tinggi akan berusaha meningkatkan pemahaman dan pengetahuannya tentang mata pelajaran Sosiologi. (2) Persepsi peserta didik atas Kompetensi Pedagogik Guru yakni tanggapan dari diri peserta didik yang diperoleh melalui proses dengan bantuan inderanya untuk mengetahui atau mengenali seperangkat kemampuan pedagogik guru dan kewenangan guru dalam melaksanakan kewajiban-kewajibannya secara bertanggung jawab dan layak yang telah diperoleh melalui pendidikan profesinya. Sehingga dari uraian-uraian diatas diduga terdapat pengaruh motivasi belajar dan persepsi peserta didik atas kompetensi pedagogik guru terhadap prestasi belajar Sosiologi.

\section{METODOLOGI}

Penelitian deskriptif ini menggunakan metode survey dengan teknik analisis korelasional dan regresi, yaitu mencari hubungan dan pengaruh antara dua variabel bebas dengan satu variabel terikat. Sedangkan data dan informasi dilapangan dijaring dengan bantuan angket atau kuesioner (questionnare).Di dalam penelitian ini terdapat tiga variabel, yaitu dua variabel independen dan satu variabel dependen. Variabel independen, yaitu; Motivasi Belajar $\left(\mathrm{X}_{1}\right)$ dan Persepsi Peserta Didik Atas Kompetensi Pedagogik Guru $\left(\mathrm{X}_{2}\right)$. Sedangkan variabel dependen yaitu Prestasi Belajar Sosiologi Peserta Didik kelas XI.

\section{Metode Pengumpulan Data}

Variabel dalam penelitian ini terdiri dari ; Variabel Terikat, yakni Prestasi Belajar Sosiologi dan Variabel Bebas, yakni Motivasi Belajar dan Persepsi Peserta Didik Atas Kompetensi Pedagogik Guru. Prestasi Belajar Sosiologi dalam penelitian ini disebut sebagai Variabel Kriteria (criterion variable). Skor variabel kriteria diperoleh dengan menggunakan instrumen untuk mengukur prestasi belajar Sosiologi. Instrumen prestasi belajar Sosiologi dikontruksikan oleh peneliti yang disesuaikan dengan kisi-kisi berdasarkan Kurikulum Tingkat Satuan Pendidikan (KTSP) Tahun Pelajaran 2012/2013. Motivasi Belajar dan Persepsi Peserta Didik Atas Kompetensi Pedagogik Guru disebut sebagai Variabel Bebas, yang merupakan Variabel Atribut. Sumber data prestasi belajar Sosiologi berasal dari data primer peserta didik kelompok sampel penelitian yang berjumlah 57 anak .Sumber data motivasi belajar dan persepsi peserta didik atas kompetensi pedagogik guru berasal dari data primer kelompok sampel penelitian berjumlah 57 anak. Bentuk kuesioner yangdipakai dalam penelitian ini adalah angket tertutup atau close from questionner yaitu kuesioner yang telah disediakan jawabannya sehingga responden dapat memilih jawabannya. Teknik pengumpulan data prestasi belajar mata pelajaran Sosiologi kelas XI dalam penelitian ini yaitu dengan cara penyebaran instrumen prestasi belajar mata pelajaran Sosiologi pada sampel yang telah ditentukan. Skor prestasi belajar Sosiologi diperoleh dengan menggunakan instrumen tes prestasi belajar Sosiologi yang telah melalui pembakuan instrumen yakni validitas, reliabilitas butir soal dan tingkat kesukaran berjumlah 32 butir soal pilihan ganda dengan ketentuan peserta didik yang menjawab benar diberi skor 1 dan yang menjawab salah diberi skor 0 . 


\section{HASIL DAN PEMBAHASAN}

Hasil analisis korelasi ganda dan regresi linear berganda untuk variabel motivasi belajar $\left(\mathrm{X}_{1}\right)$ dan variabel persepsi peserta didik atas kompetensi pedagogik guru $\left(\mathrm{X}_{2}\right)$ terhadap variabel Prestasi Belajar Sosiologi $(\mathrm{Y})$ menggunakan program SPSS 17.0 disajikan pada tabel 1, 2, dan 3 berikut :

Tabel 1. Hasil Analisis Korelasi Ganda $X_{1}$ dan $X_{2}$ Terhadap Y

Model Summary

\begin{tabular}{ccccc} 
Model & R & R Square & $\begin{array}{c}\text { Adjusted R } \\
\text { Square }\end{array}$ & $\begin{array}{c}\text { Std. Error of the } \\
\text { Estimate }\end{array}$ \\
\hline 1 & $.827^{\mathrm{a}}$ & 0.684 & 0.672 & 7.91742 \\
\hline
\end{tabular}

a. Predictors: (Constant), Persepsi Peserta Didik, Motivasi Belajar

Tabel 2. Hasil Ringkasan ANOVA Untuk Uji Signifikan

\begin{tabular}{|c|c|c|c|c|c|c|}
\hline \multicolumn{7}{|c|}{ ANOVA $^{b}$} \\
\hline Model & & $\begin{array}{c}\text { Sum of } \\
\text { Squares }\end{array}$ & df & $\begin{array}{c}\text { Mean } \\
\text { Square }\end{array}$ & $\mathrm{F}$ & Sig. \\
\hline \multirow[t]{3}{*}{1} & Regression & 7323.856 & 2 & 3661.928 & 58.417 & $.000^{\mathrm{a}}$ \\
\hline & Residual & 3385.021 & 54 & 62.686 & & \\
\hline & Total & 10708.877 & 56 & & & \\
\hline
\end{tabular}

a. Predictors: (Constant), Persepsi Peserta Didik, Motivasi Belajar

b. Dependent Variable: Prestasi Belajar

Tabel 3. Hasil Analisis Regresi Linear Berganda $X_{1}$ dan $X_{2}$ Terhadap $Y$

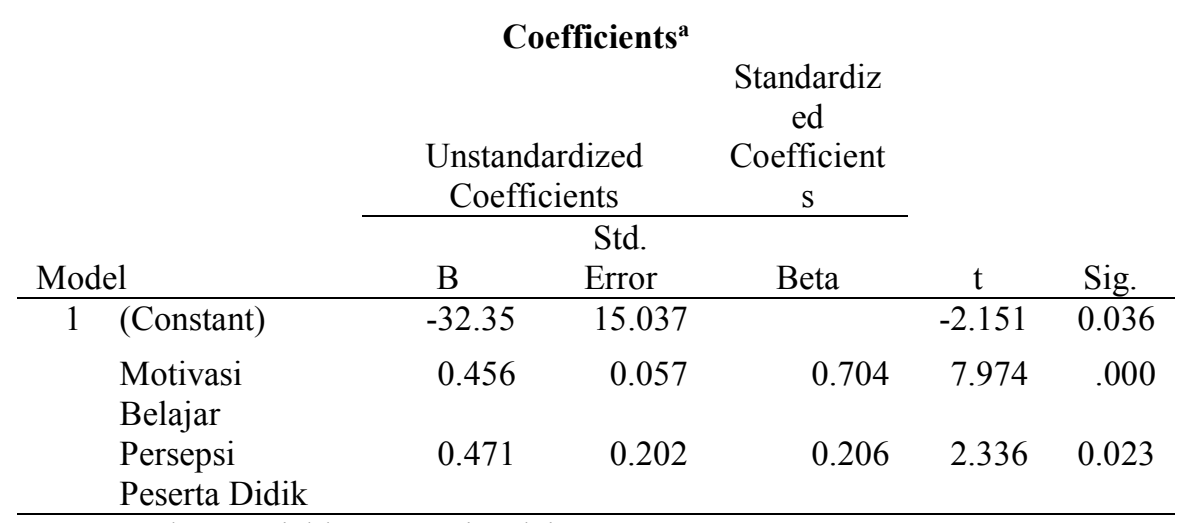

a. Dependent Variable: Prestasi Belajar

\section{Pengaruh Motivasi Belajar $\left(\mathrm{X}_{1}\right)$ dan Persepsi Peserta Didik Atas Kompetensi Pedagogik Guru $\left(\mathrm{X}_{2}\right)$ Secara Bersama-sama Terhadap Prestasi Belajar Sosiologi (Y).}

Berdasarkan hasil analisis pada Tabel 1 di atas, nilai koefisien korelasi ganda $\mathrm{R}$ adalah 0.827 , hal ini menunjukan bahwa terjadi hubungan yang sangat kuat antara variabel motivasi belajar $\left(\mathrm{X}_{1}\right)$ dan variabel persepsi peserta didik atas kompetensi pedagogik guru $\left(\mathrm{X}_{2}\right)$ terhadap variabel Prestasi Belajar Sosiologi (Y).

Nilai koefisien determinasi atau $\mathrm{R}$ square atau $\mathrm{R}^{2}$ adalah sebesar 0.684 atau $68.4 \%$. Hal ini menunjukan bahwa kontribusi pengaruh variabel motivasi belajar $\left(\mathrm{X}_{1}\right)$ dan variabel persepsi peserta didik atas kompetensi pedagogik guru $\left(\mathrm{X}_{2}\right)$ 
terhadap variabel Prestasi Belajar Sosiologi (Y) sebesar $68.4 \%$. Sedangkan sisanya sebesar $31.6 \%$ dipengaruhi oleh variabel lain yang tidak dimasukan dalam model penelitian ini.

Persamaan regresi linear berganda berdasarkan atas hasil analisis yang ada pada tabel 3 adalah sebagai berikut :

$$
\mathrm{Y}=-32.35+0.456 \mathrm{X}_{1}+0.471 \mathrm{X}_{2}
$$

Persamaan regresi di atas dapat dijelaskan sebagai berikut :

1. Konstanta sebesar -32.35 artinya jika motivasi belajar dan persepsi peserta didik atas kompetensi pedagogik guru nilainya 0 maka, nilai prestasi belajar adalah 32.35 .

2. Koefisien regresi variabel motivasi belajar $\left(\mathrm{X}_{1}\right)$ sebesar 0.456 , artinya jika variabel independen lain nilainya tetap, maka jika nilai motivasi belajar mengalami kenaikan 1 poin maka nilai prestasi belajar akan mengalami kenaikan sebesar 0.456 . Koefisien bernilai positif artinya jika semakin tinggi nilai motivasi belajar maka semakin meningkat nilai prestasi belajar.

3. Koefisien regresi variabel persepsi peserta didik atas kompetensi pedagogik guru $\left(\mathrm{X}_{2}\right)$ sebesar 0.471 , artinya jika variabel independen lain nilainya tetap, maka jika nilai persepsi peserta didik atas kompetensi pedagogik guru mengalami kenaikan 1 poin maka nilai prestasi belajar akan mengalami kenaikan sebesar 0.471 . Koefisien bernilai postif artinya jika semakin tinggi nilai persepsi peserta didik atas kompetensi pedagogik guru maka semakin meningkat nilai prestasi belajar.

Untuk menguji signifikansi antara variabel motivasi belajar $\left(\mathrm{X}_{1}\right)$ dan variabel persepsi peserta didik atas kompetensi pedagogik guru $\left(\mathrm{X}_{2}\right)$ secara bersama-sama terhadap variabel Prestasi Belajar Sosiologi (Y) maka digunakan Uji F. Untuk melakukan Uji F ini maka penentuan hipotesis terlebih dahulu, dimana hipotesis yang diuji adalah sebagai berikut :

$\mathrm{H}_{0}$ : Tidak terdapat pengaruh signifikan motivasi belajar dan persepsi peserta didik atas kompetensi pedagogik guru secara bersama-sama terhadap prestasi belajar Sosiologi.

$\mathrm{H}_{\mathrm{a}}$ : Terdapat pengaruh signifikan motivasi belajar dan persepsi peserta didik atas kompetensi pedagogik guru secara bersama-sama terhadap prestasi belajar Sosiologi.

Dengan kriteria pengujian adalah sebagai berikut :

$\mathrm{H}_{0}$ ditolak dan $\mathrm{H}_{\mathrm{a}}$ diterima jika $\mathrm{F}$ hitung $>\mathrm{F}$ tabel atau sig $<0.05$

$\mathrm{H}_{0}$ diterima dan $\mathrm{H}_{\mathrm{a}}$ ditolak jika $\mathrm{F}$ hitung $<\mathrm{F}$ tabelatau sig $>0.05$

Dari tabel 2 di atas dapat diketahui bahwa $\mathrm{F}_{\text {hitung }}$ adalah 58.417 dan dengan menggunakan taraf nyata $\alpha=5 \%, \mathrm{n}=$ jumlah responden dan $\mathrm{m}=$ jumlah variabel bebas, maka didapatkan $\mathrm{F}_{\text {tabel }}=\mathrm{F}_{((\mathbf{1}-\mathbf{\alpha})(\mathbf{d k} \text { pembilang }=\mathbf{m}),(\mathbf{d k} \text { penyebut }=\mathbf{n}-\mathrm{m}-\mathbf{1}))}=\mathrm{F}_{(\mathbf{0 . 9 5 ( 2 )}(\mathbf{5 7 - 2}-}$ ${ }_{1)}=\mathrm{F}(\mathbf{0 . 9 5 ( 2 ) ( 5 4 )}=3.172$. Karena $F$ hitung $>F$ tabel, dan nilai Sig adalah $0.000<0.05$, maka $\mathrm{H}_{0}$ ditolak, sehingga dapat disimpulkan bahwa terdapat pengaruh signifikan motivasi belajar dan persepsi peserta didik atas kompetensi pedagogik guru secara bersama-sama terhadap prestasi belajar Sosiologi.

Hasil analisis menggunakan SPSS 17.0 yang ada pada tabel 1 didapatkan bahwa besarnya nilai koefisien korelasi (R) adalah 0.827 yang menunjukan 
keeratan hubungan yang sangat kuat antara variabel bebas motivasi belajar $\left(\mathrm{X}_{1}\right)$ dan variabel bebas persepsi peserta ddik atas kompetensi pedagogik guru dengan variabel terikat prestasi belajar Sosiologi (Y).

Selain itu nilai koefisien determinasi $\left(\mathrm{R}^{2}\right)$ adalah sebesar 0.684 yang menunjukan bahwa sumbangan pengaruh variabel motivasi belajar dan persepsi peserta didik atas kompetensi pedagogik guru atas prestasi belajar Sosiologi adalah sebesar $68.4 \%$, sedangkan sisanya sebesar $31.6 \%$ berasal dari pengaruh faktorfaktor lain.

Berdasarkan informasi kuantitatif dan teori-teori tersebut, penelitian ini secara umum telah menemukan dan membuktikan bahwa terdapat pengaruh signifikan Motivasi Belajar dan Persepsi Peserta Didik atas Kompetensi Pedagogik Guru secara bersama-sama terhadap Prestasi Belajar Sosiologi.

\section{SIMPULAN DAN SARAN \\ Simpulan}

Terdapat pengaruh yang signifikan motivasi belajar dan persepsi peserta didik atas kompetensi pedagogik guru secara bersama-sama terhadap prestasi belajar Sosiologi. Hal ini dibuktikan dengan hasil pengujian regresi linear berganda, yaitu $F_{\text {hitung }}>F_{\text {tabel }}$. Dimana $F_{\text {hitung }}=58.417$ dan $F_{\text {tabel }}=3.17$.

\section{Saran}

Berdasarkan simpulan tersebut diatas, peneliti mengemukakan beberapa saran sebagai berikut;

1. Guru seyogyanya terus-menerus meningkatkan kualifikasi profesionalnya, disamping mampu mengembangkan kurikulum, serta menguasai kelas dan mengatur strategi pembelajaran. Sebab Guru selalu dituntut dapat mengusai materi pelajaran secara interdisipliner, hal ini penting karena dalam proses pembelajaran Ilmu Pengetahuan Sosial (IPS) khususnya Sosiologi diperlukan pendekatan multidimensional. Guru dituntut untuk memiliki kompetensi pedagogik yang disyaratkan sebagai seorang profesional.

2. Para Guru, para pengelola lembaga pendidikan, serta para orang tua senantiasa selalu memberikan motivasi kepada para peserta didik atau siswa agar tetap memiliki semangat belajar yang tinggi, berkompetisi, dan berprestasi untuk meraih kesuksesan.

3. Para Kepala Sekolah, para pengelola pendidikan, dan instansi pemerintah yang menangani pendidikan, turut berperan aktif untuk melakukan upaya-upaya yang dapat meningkatkan kompetensi Pedagogik Guru. Hal tersebut penting dilaksanakan sebab pada dasarnya Guru memegang peranan yang sangat strategis dalam keseluruhan proses kegiatan belajar mengajar di sekolah.

4. Hendaknya para Guru dan para pengelola lembaga pendidikan dapat bersinergi dalam memadukan motivasi belajar peserta didik dengan kompetensi pedagogik Guru, agar prestasi belajar peserta didiknya yang tinggi dapat tercapai.

5. Perlunya penelitian lebih lanjut dalam mengembangkan teori dan konsep tentang motivasi belajar, persepsi peserta didik atas kompetensi pedagogik guru, dan prestasi belajar Ilmu Pengetahuan Sosial (IPS) khususnya Sosiologi, serta menelitinya secara empirik. 
Research and Development Journal Of Education

Vol. 2 No. 2 April 2016

ISSN 2406-9744

\section{DAFTAR RUJUKAN}

Ahmadi, Iif Khoiru., dan Amri, Sofan. 2011. Metode Pembelajaran Terpadu : Analisis Kritis Tentang Metode, Strategi, Evaluasi, dan Media Pembelajaran Bidang Studi Sejarah, Ekonomi, Sosiologi, Antropologi, dan Isu Pembelajaran IPS Terpadu. Jakarta : Prestasi Pustakaraya.

Djamarah, Syaiful Bahri. 2008. Psikologi Belajar. Jakarta : Rineka Cipta.

Departemen Pendidikan Nasional. 2005. Kamus Besar Bahasa Indonesia. (ed. ketiga). Jakarta : Balai Pustaka.

Fathurrohman, Pupuh., dan Sutikno, M. Sobry. 2009. Strategi Belajar Mengajar : Strategi Mewujudkan Pembelajaran Bermakna Melalui Penanaman Konsep Umum dan Konsep Islami. Bandung : Refika Aditama.

M, Sardiman A. 2006. Interaksi dan Motivasi Belajar Mengajar. Jakarta : Raja Grafindo Persada.

Mulyasa, Encon. 2009. Standar Kompetensi dan Sertifikasi Guru. Bandung: Remaja Rosdakarya.

.2009. Menjadi Guru Profesional : Menciptakan Pembelajaran Kreatif dan Menyenangkan. Bandung :Remaja Rosdakarya.

Pidarta, Made. 2007. Landasan Kependidikan : Stimulus Ilmu Pendidikan Bercorak Indonesia. Jakarta : Rineka Cipta.

Purwanto. 2011. Evaluasi Hasil Belajar. Yogyakarta : Pustaka Pelajar.

Sarwono, Sarlito W.2010. Pengantar Psikologi Umum. Jakarta : Rajawali Pers.

Slameto. 2010. Belajar dan Faktor-faktor yang Mempengaruhinya. (ed. rev).Jakarta : Rineka Cipta.

Syah, Muhibbin. 2001. Psikologi Pendidikan dengan Pendekatan Baru. Bandung : Remaja Rosdakarya.

Undang-Undang Republik Indonesia Nomor 14 tahun 2005, 2010, Bandung, Citra Umbara.

Uno, Hamzah B. 2008. Teori Motivasi dan Pengukurannya : Analisis di Bidang Pendidikan. Jakarta : Bumi Aksara. 